\title{
Research on Performance Management of Reading Promotion Activities in Public Libraries
}

\author{
Qianqian Si' ${ }^{1}$ Jiayin Liu'1, Qing Chen² \\ ${ }^{1}$ Library, Nanjing University of Aeronautics and Astronautics, Nanjing, China \\ ${ }^{2}$ Library, Shanghai Civil Aviation College, Shanghai, China \\ Email: siqianqian@shcac.edu.cn
}

How to cite this paper: Si, Q.Q., Liu, J.Y. and Chen, Q. (2019) Research on Performance Management of Reading Promotion Activities in Public Libraries. Open Access Library Journal, 6: e5921.

https://doi.org/10.4236/oalib.1105921

Received: November 14, 2019

Accepted: November 25, 2019

Published: November 28, 2019

Copyright $\odot 2019$ by author(s) and Open Access Library Inc.

This work is licensed under the Creative Commons Attribution International License (CC BY 4.0).

http://creativecommons.org/licenses/by/4.0/

\begin{abstract}
This paper introduces the performance management method into the management of public libraries' reading promotion activities. The literature analysis method and the empirical research method are used to study its scientific rationality to promote the enthusiasm of librarians and improve the efficiency of reading promotion activities.
\end{abstract}

\section{Subject Areas}

Library, Intelligence and Philology

\section{Keywords}

Reading Promotion, Performance Management, Key Performance Indicators, Balanced Scorecard, Public Libraries

\section{Introduction}

According to Peter Drucker, the founder of management, "all organizations should think about what performance is." Performance is an issue that an organization has to care about. In different scenarios, the understanding of performance is also different. As Bates said, "performance is a multi-dimensional construction, and different perspectives of observation and measurement lead to different results" [1]. In general performance evaluation, there are three levels of consideration: organization, group and individual. The main factors affecting performance are skills, environment, incentives and opportunities. The scope of performance evaluation is very wide, including many assessment factors. The factors commonly used in the company's performance evaluation include quali- 
ty, time, quantity and cost.

At present, the results of public librarian's evaluation have little impact on the work content or salary, while it will have a certain impact on promotion, evaluation and other aspects. Public libraries should take appropriate measures of rewards and punishments, which will help to arouse the enthusiasm of librarians, stimulate their innovative spirit and enhance the attraction of activities. Based on practical investigation, presently district-level public libraries in Shanghai have not yet formulated the performance evaluation methods for reading promotion activities. Only Wuxi Library in the prefecture-level city libraries in southern Jiangsu Province has performance appraisal standards, but no system has yet been formed. Wuxi Library has set up performance evaluation standards for activities. There are three work and personal summaries each year including annual, semi-annual and year-end summary.

\section{The Significance of Performance Management in Reading Promotion Project}

How to conduct performance appraisal of reading promotion work in public libraries is a management method that is easily ignored [2]. At present, most public libraries do not implant this management method in the reading promotion project. How to formulate standards and how to implement it are still very vague, and even think that this is a dispensable method. Observing the status of the activity on the scene has become an important criterion for most public libraries to evaluate the success of activities, such as the response and participation of the reader on the spot. Obviously, the success of the activity cannot be simply evaluated in this way. Performance management is a set of criteria for systematic evaluation of activity quality. Therefore, it is necessary to introduce a scientific management method-performance management into reading promotion projects, find out the key points of performance management evaluation, and deeply explore its evaluation criteria and scope. Performance management is a management method for setting and achieving goals, enhancing the attractiveness and self-confidence of employees to achieve goals [3].

In recent years, performance management has been increasingly applied to government, enterprises and institutions management and other fields. Public libraries reading promotion activities belong to public welfare activities, which are different from the ultimate goal of performance management of traditional companies. The goal of general companies is profit, while the goal of performance management of reading promotion activities is to improve the influence of activities and serve more people. Although the goal of performance management of public libraries is different from that of traditional company, the overall idea is not much different. In the performance management design of public libraries reading promotion activities, the uniqueness of performance evaluation methods and process should be considered. 


\section{Performance Management Process}

\subsection{Performance Plan}

Performance plan and activity plan are not the same concept. Performance plan is the first link and starting point of performance management. It plays a crucial role in the performance management cycle. Performance plan includes two aspects: what to do and how to do it [4]. What to do is the goal of the reading promotion project, and how to do mean the action to achieve the goal. Performance plan is a means to promote the realization of the organization's goals through personal performance expectations, so performance plan should be carried out under the organization's goals, and there should be a relevant team in the organization to make overall arrangements for this work.

\subsection{Performance Implementation}

Performance implementation includes three aspects: performance communication, performance information collection and performance guidance. Performance communication refers to the sharing of various performance-related information and processes between employees and managers in the process of working together. Performance information collection refers to the collection of information closely related to work performance. Performance coaching refers to that in daily work, the manager should find out the problems of subordinates and correct them through specific methods and means to meet the work requirements and cultivate their abilities required in daily work. In the process of performance implementation, managers need to master the work content and progress from a global perspective to ensure the quality and quantity of work to be completed on schedule. They have to supervise subordinates and provide them with the help, guidance and assistance they need to complete their work with high quality [5].

\subsection{Performance Evaluation}

Performance evaluation, also known as performance appraisal, is most commonly used in human resource management systems. In short, performance evaluation is the objective feedback of employees to complete a certain work. Scientific performance evaluation includes the following contents: performance evaluation, ability evaluation, attitude evaluation and potential evaluation [6]. Generally, the commonly used performance evaluation methods can be divided into three types: first, result-oriented performance evaluation methods, such as performance evaluation form method, objective management method, key performance indicator method, etc.; second, behavior-oriented performance evaluation methods, such as key event method, behavior observation comparison method, behavior anchor evaluation method, 360-degree performance evaluation method, etc.; third, characteristic performance evaluation methods, such as graphical evaluation scale, etc. 


\subsection{Performance Feedback}

Performance feedback is to feedback the results of performance evaluation to the evaluated object and influences the behavior of the evaluated object. Performance feedback is a performance management tool to let employees know their own performance level, and it is the most important form of performance communication. The main content of performance feedback includes the following four aspects: first, timely feedback the current performance appraisal results to employees. Make employees know the general position of their performance in the whole organization and stimulate their willingness to improve the current performance level. Second, analyze the performance gap of employees and identify improvement measures. Through the feedback of performance results and the experience of performance achievement, find out the reasons for the failure of work performance, to lay a foundation for better completion of the work in the future. Third, communicate and negotiate the tasks and objectives of the next performance appraisal cycle. In this session, the performance of the previous performance cycle and the new work tasks of the employees should be combined to propose new work objectives in the next performance cycle. Fourth, determine the allocation of resources that match the task objectives. Determining appropriate resource allocation is a win-win process for both managers and employees. For employees, resources are available to complete the task. For the supervisor, the limited resources can be integrated to make the maximum use of the limited resources.

\subsection{Performance Improvement}

Performance improvement means that when there is a gap between the completion of the work and the goal setting, we need to test the work to determine which aspects of the work are problematic. If we find the problem, we need to improve it. Only by identifying the gaps and shortcomings can we better determine new goals or change working methods and constantly improve competitiveness. The process of making performance improvement plan includes: first, reviewing the results of performance appraisal. Supervisors and employees can communicate on the content of the performance evaluation form item by item, and then start to develop a performance improvement plan after the two parties basically agree on the contents of the performance evaluation. Second, identify projects that need to be developed. Projects that need to be developed are usually those that need to be improved in terms of capabilities, methods, habits, etc. Third, determine specific measures for development. Methods that used to improve employee performance include training, soliciting feedback from others, job rotation, attending task teams, participating in certain associations, and more. Fourth, list the resources needed for development. List the resources needed to achieve the desired level of employee development and indicate which resources need the help and support of the supervisor. Fifth, clarify the evaluation period of the project. It is a long-term task to improve the working ability, 
methods and habits of employees, which can only be accurately evaluated in a long period of time.

\section{The Application of Two Common Performance Management Methods in Reading Promotion Activities}

\subsection{Balanced Scorecard}

The balanced scorecard, originated in the United States in the 1990s, is a kind of performance evaluation system. Generally, enterprises quantify the organization's strategy from four dimensions of finance, customers, internal operation, learning and growth into an operable performance evaluation index and a new performance management means of setting the target value [7]. After 20 years of development, the balanced scorecard has become one of the important tools of corporate strategic management, playing an important role in goal planning and executive management. The function of the balanced scorecard is to prevent the set goal strategy from being divorced from the actual work, which helps to reduce the possibility of detours.

Compared with the traditional financial accounting assessment method, the balanced scorecard can effectively consider the direction of project development and prepare for prediction in advance. Different from the traditional financial accounting assessment method, in addition to financial indicators, it adds three indicators, namely Customer, Internal Business Processes and Learning and Growth. The assessment is more comprehensive and the results are more scientific and rigorous [6].

The use of balanced scorecard performance management tools in reading promotional activities is quite different from that in general enterprises. Therefore, based on the particularity of the research object, this paper focuses on the reader dimension rather than the financial dimension of general enterprises. Figure 1 is present to show balanced scorecard of reading promotion activities.

\subsubsection{Reader Dimension}

The reader dimension is to measure the output value of reading promotion activities from the perspective of performance production, and it is the ultimate value embodiment of reading promotion projects. There are many measurement standards, such as: the number of readers participating in the activities, the on-site performance status of readers, readers' feedback, the continuous influence of the activities, etc., which are obtained through qualitative and quantitative research. This dimension is the most direct expression of activity success.

\subsubsection{Financial Dimension}

Financial dimension is applied to the cost control of reading promotion activities. Different from the performance management method of balanced scorecard used by general enterprises, what the company produces is product, and what it returns is profit. Reading promotion activities produce activity provision and return readers' preferences. However, the application of financial dimension in 


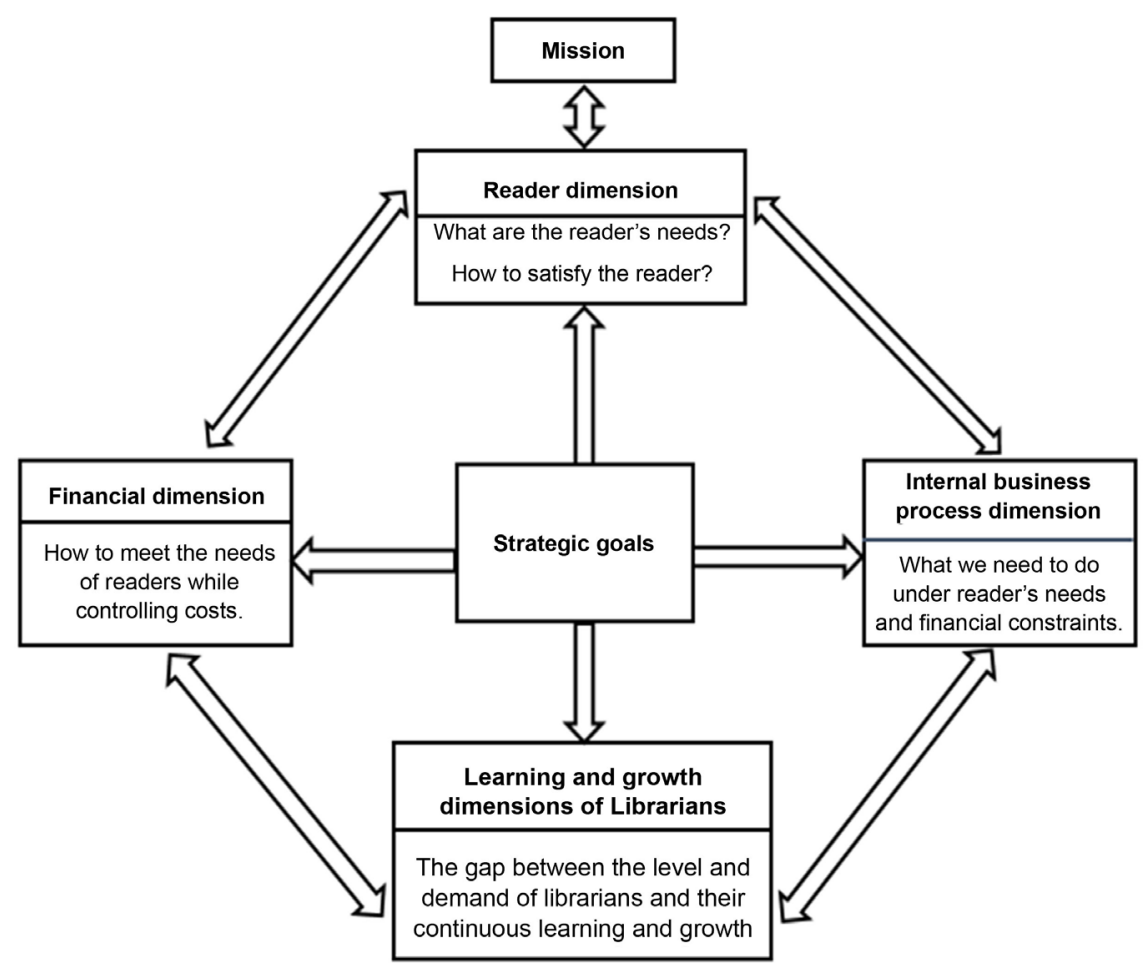

Figure 1. Balanced scorecard of reading promotion activities.

reading promotion projects is still very important, which is directly reflected in the cost control. Activities need cost input, but the same cost input and output are not the same. For example, the same activities, the same supporting facilities, the same manpower input, but there will be differences in the number of readers present. The reasons may lie in the publicity, time setting, and different emphasis. Under such circumstances, it is necessary to consider the financial dimension of performance management, and how to make readers get more utility with less capital investment. This dimension is an indirect manifestation of the success of the activity.

\subsubsection{Internal Business Process Dimension}

The dimension of internal business process reflects the business level of the group responsible for reading promotion activities. The first step of this dimension is to establish the core value chain of librarians, replace the old service idea with a new service idea that can meet the needs of readers, and create a complete internal process value chain that can solve existing problems. The internal value chain module of public libraries reading promotion project includes three processes: innovation, reader service and follow-up work; its internal business process dimension measurement module includes three aspects: organization, business process and management mechanism. This dimension is the key to the success of reading promotion projects.

\subsubsection{Learning and Growth Dimension}

Indicators of financial dimension, reader dimension and internal business 
process dimension have established the overall goal construction of reading promotion activities, while growth learning module is the cornerstone. Without learning and growth, nothing can be done well. This dimension is the cornerstone of the sustainability of reading promotions, which is reflected in how to evaluate and improve the activities. There are two kinds of indicators for learning and growth dimension: professional training and learning communication. The promotion of librarians' ability is the intangible asset for the sustainable development of reading promotion activities, which is conducive to the promotion of activities. Only by procrastinating continuous learning and innovation can we make continuous progress. As shown in Table 1, detailed balanced scorecard indicators of reading promotion activities are present.

\subsection{Key Performance Indicators (KPI)}

\subsubsection{Definition of Key Performance Indictors}

The whole activity process: conduct qualitative and quantitative research and judgment on key performance assessment factors from input to output, quantify them into manageable indicators, and decompose strategic objectives into steps

Table 1. Balanced scorecard indicators of reading promotion activities.

\begin{tabular}{|c|c|c|c|}
\hline First level index & Second level index & Index calculation method & Remark \\
\hline \multirow{4}{*}{ Reader dimension } & Reader satisfaction & Use survey method to obtain evaluation value & $\begin{array}{l}\text { Readers' satisfaction with the quality and } \\
\text { service of reading promotion activities }\end{array}$ \\
\hline & Number of readers & Take statistical method to obtain evaluation value & $\begin{array}{l}\text { Number of participants and participants } \\
\text { in we-media activities, repeated } \\
\text { participation, }\end{array}$ \\
\hline & State of on-site activity & Use observation method to obtain evaluation value & Readers' status at the event site \\
\hline & Continuous influence & $\begin{array}{l}\text { Use grading qualitative method to obtain } \\
\text { evaluation value }\end{array}$ & $\begin{array}{l}\text { Evaluate the influence of the activity and } \\
\text { its influence on the later activities }\end{array}$ \\
\hline \multirow{4}{*}{$\begin{array}{l}\text { Internal business } \\
\text { process } \\
\text { dimension }\end{array}$} & Innovation effect & $\begin{array}{l}\text { Use investigation report method to obtain } \\
\text { evaluation value }\end{array}$ & $\begin{array}{l}\text { Assess the impact of innovation on } \\
\text { business processes }\end{array}$ \\
\hline & $\begin{array}{l}\text { Professional ability of } \\
\text { librarians }\end{array}$ & $\begin{array}{l}\text { Use personal performance evaluation method to } \\
\text { obtain evaluation value }\end{array}$ & $\begin{array}{l}\text { Reading promotion is responsible for the } \\
\text { accomplishment of librarians' } \\
\text { performance appraisal }\end{array}$ \\
\hline & $\begin{array}{l}\text { Department organization } \\
\text { efficiency }\end{array}$ & $\begin{array}{l}\text { Use expert scoring method to obtain evaluation } \\
\text { value }\end{array}$ & $\begin{array}{l}\text { Evaluation of the influence of } \\
\text { organizational efficiency on activities }\end{array}$ \\
\hline & $\begin{array}{l}\text { Business capability of } \\
\text { management }\end{array}$ & $\begin{array}{l}\text { Use personal performance evaluation method to } \\
\text { obtain evaluation value }\end{array}$ & $\begin{array}{l}\text { The influence of high level of public } \\
\text { libraries on reading promotion activities }\end{array}$ \\
\hline \multirow{2}{*}{$\begin{array}{l}\text { Learning and } \\
\text { growth }\end{array}$} & Professional training & $\begin{array}{l}\text { Use expert scoring method to obtain evaluation } \\
\text { value }\end{array}$ & $\begin{array}{l}\text { Librarian's professional level update and } \\
\text { content learning }\end{array}$ \\
\hline & Study and exchange & $\begin{array}{l}\text { Use expert scoring method to obtain evaluation } \\
\text { value }\end{array}$ & $\begin{array}{l}\text { Participate in academic conferences, peer } \\
\text { discussion }\end{array}$ \\
\hline \multirow{2}{*}{$\begin{array}{l}\text { Financial } \\
\text { dimension }\end{array}$} & Equipment depreciation & Annual depreciation/Original price of equipment & $\begin{array}{l}\text { Proportion of annual equipment } \\
\text { expenditure }\end{array}$ \\
\hline & $\begin{array}{l}\text { Activity financial } \\
\text { expenditure rate }\end{array}$ & Reading promotion expenses/annual expenditure & $\begin{array}{l}\text { Proportion of annual reading promotion } \\
\text { expenses }\end{array}$ \\
\hline
\end{tabular}


and specific work objectives of each member, which is the key performance indicator method [8]. The project leader shall make clear the main responsibilities of the project, the main work of the subordinate departments and the setting of performance evaluation indicators.

Public libraries reading promotion project target segmentation: reading promotion target setting is usually in four aspects: funding, strategic goal, organization and coordination, and value embodiment. The fund is how to increase the income and reduce the expenditure of public libraries reading promotion activities and improve the maximum utility of each penny. The strategic goal is how to get more readers to participate in reading promotion activities and improve the utility of readers. Organization \& coordination is how to build a strong organization and retain talents, absorb talents, talent training, etc. The value of reading promotion activities reflects the value and the competitiveness of public libraries, the concept of work, professional skills, etc.

The establishment of objectives will make project participants clear the direction of their efforts. When all project participants are in the same direction, they will move towards the strategic direction of the project, as shown in Figure 2, which will form a value system with clear objectives [9].

Using KPI key performance indicator method, the first step is to determine the objectives of reading promotion activities. At present, few public libraries are specific to a department or a person in reading promotion, and the objectives are definitely not clear when responsibilities are scattered. Professor Fan Bingsi pointed out that the ultimate goal of reading promotion is to improve citizens' literacy through reading, with the focus on special groups. This goal is obviously not easy to be measured by indicators, but it can be indirectly measured by some indicators to confirm the quality of activities, such as the number of participants, on-site response, readers' feedback, organizational efficiency and other indicators. In view of these indicators, the goal of reading promotion project can be set to increase the number of participants, improve the on-site atmosphere and enhance the impression of readers after the activity through some means.

There are two parts in the goal of the key performance appraisal method. In addition to the basic goal of the project, the challenging goal of the key performance index should also be set. The basic goal is established considering the rationality and foundation of achievement, and the challenge goal is the highest expected value of the project [10].

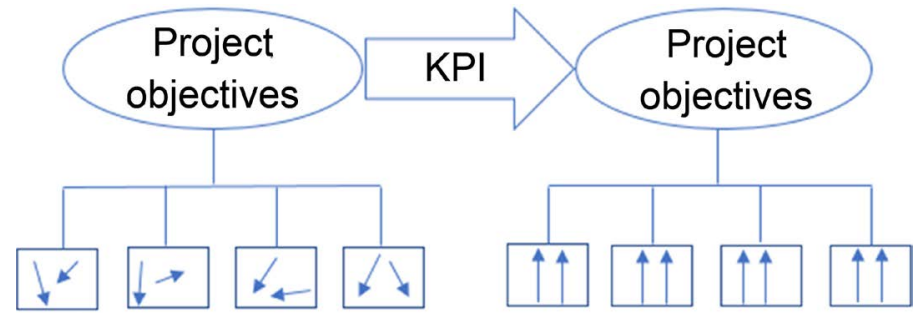

Figure 2. The KPI target diagram of reading promotion activities. 


\subsubsection{Advantage of Key Performance Indicator Method (KPI)}

1) With the decomposition of the project objectives, managers can clearly recognize the key objectives of the project.

2) It can easily analyze the key factor drivers and effectively diagnose the existing problems of the project.

3) Highlight the key behaviors of the project, and make the managers focus on the key issues.

4) Use qualitative and quantitative indicators to promote the strategic objectives of the project.

5) Make the project strategic objectives of all members and departments consistent, and enhance effective communication.

At present, many enterprises begin to pay attention to the advantages of KPI, and try to apply the key performance indicator method (KPI) into the actual operation of enterprises to achieve the strategic goals of the company [11]. Public libraries reading promotion projects can also use KPI to implement the strategic objectives of the project, highlight the key factors of the project, and enhance the cohesion of project members.

\subsubsection{Value Tree Model}

Value tree is a direct description of the value system of reading promotion activities. Find the corresponding logical relationship in the key indicators of the reading promotion project, establish the corresponding strategic objectives, corresponding key performance indicators, the process and corresponding indicators to drive these key indicators, the corresponding responsible persons and departments. The displayed objectives, performance indicators, driver processes and corresponding indicators should be closely linked with the strategic theme to form a causal relationship [12]. See Table 2 for the value tree model of reading promotion performance management.

Table 2. Reading promotion performance management value tree model.

\begin{tabular}{|c|c|c|}
\hline Strategic theme & Key Performance Indicators & Key driving process \\
\hline \multirow[t]{2}{*}{ Funding guarantee } & $\begin{array}{l}\text { Broaden sources of income } \\
\text { and reduce expenditure }\end{array}$ & Increase financial allocation \\
\hline & & Increase maximum utility per cent \\
\hline \multirow[t]{2}{*}{ strategic target } & Number of readers & Propaganda means and strength \\
\hline & & Enhance the attraction of the event \\
\hline \multirow[t]{2}{*}{$\begin{array}{l}\text { Organization and } \\
\text { coordination }\end{array}$} & Integrate various resources & $\begin{array}{l}\text { Improve efficiency } \\
\text { Reduce waste of personnel and materials }\end{array}$ \\
\hline & & Attract and cultivate talents \\
\hline \multirow[t]{3}{*}{ Value embodiment } & Core competitiveness & Highlight the core value of Public Library \\
\hline & & Improve innovation awareness \\
\hline & & Improve service awareness \\
\hline
\end{tabular}




\section{Conclusion}

Performance management is a set of mature management methods, which is widely used in enterprise management. The method of performance management is introduced into the reading promotion service of public libraries to improve the potential of librarians, the enthusiasm of their work and the efficiency. This paper introduces the concept of performance management, the significance and process of performance management and two common methods of performance appraisal. It decomposes the objectives of reading promotion and demonstrates the possibility and scientific of introducing performance management into the assessment of reading promotion activities from different dimensions. However, there are some limitations in this paper. As the samples in this paper are from Shanghai district-level public libraries and prefecture-level city libraries in southern Jiangsu Province, whether there is a well-developed performance management public library outside the survey samples remains to be further investigated and studied. In addition, performance evaluation is mainly used in enterprise personnel management. It is a new research field to introduce performance evaluation into reading promotion activities, and its scientific nature remains to be further explored.

\section{Acknowledgements}

Our team worked very hard during the project research. We extend our deepest thanks to all those who have supported us a lot during the research.

\section{Conflicts of Interest}

The authors declare no conflicts of interest regarding the publication of this paper.

\section{References}

[1] Lin, X.Q. (2011) Performance Appraisal and Performance Management. University of Foreign Economic and Trade Press, Beijing.

[2] Lu, M.M. and Fang, X.M. (2015) Study on the Construction of Performance Evaluation Index System of Reading Promotion Activities in University Public Library. Public Library Construction, 11, 34-37.

[3] Wang, Z. (2010) Breaking through the Bottleneck of Assessment. Shanghai Business, 10, 1007-2845.

[4] Yun, P. and Yin, H.Y. (2015) Performance Management. China Business Press, Beijing.

[5] Zhang, Y.K. (2016) Problems and Countermeasures of Performance Management in Small and Medium-Sized Enterprises. Chinese and Foreign Entrepreneurs, 11, 153-154.

[6] Wang, J.D. (2004) Multidimensional Evaluation of Post-Performance of Public Libraries. Public Library Forum, 4, 66-69.

[7] Qin, Y.Y. (2005) Balanced Scorecard and Performance Management. China Economic Press, Beijing. 
[8] Wang, S.Q., Yang, B. and Zhang, Q. (2008) KPI: Development, Implementation and Application of KPI. China Machine Press, Beijing.

[9] Feng, X.F. (2016) The Design of the Key Performance Index Evaluation System of Higher Vocational Colleges Based on the Strategic Objective: A Case Study of Zhejiang Industrial Vocational and Technical College. Vocational Education, 4, 41-44.

[10] Zheng, Y.H. (2014) Application Analysis of Key Performance Assessment Method in Enterprise Management. Office Business, No. 7, 23+42.

[11] Hui, Z.N. (2016) Analysis of Performance Appraisal System Based on KPI Key Performance Indicators. Enterprise Reform and Management, 14, 48-49.

[12] Qin, Y.Y. (2012) Analysis of Classic Cases of Balanced Scorecard and Performance Management. China Economic Press, Beijing. 